\title{
NUTRIENT, NON-NUTRIENT AND SENSORY PROFILE OF PEELED AND UNPEELED DIKA (IRVINGIA GABONENSIS) FRUIT JUICE
}

\author{
Vivienne Nkiru Ibeanu, Peace Nwanneka Ani ${ }^{\bowtie}$, Peter Ndubuisi Eze \\ Department of Nutrition and Dietetics, University of Nigeria, Nsukka \\ P.O. Box 3042, Nsukka, Enugu State, Nigeria
}

\begin{abstract}
Background. Many underutilized wild fruits offer potential novel sources of macro- and micro-nutrients, as well as health-promoting antioxidants and phytochemicals. However, these benefits are not fully harnessed due to limited information on their composition. Dika fruit is one of such underutilized wild fruits. This study was carried out to analyze juice samples processed from dika fruit for nutrient and non-nutrient contents, as well as for their sensory attributes.

Materials and methods. Fruits harvested from rural communities in Nsukka, Enugu State, Nigeria were washed and divided into two portions. The skin of one portion was peeled off and sliced into small pieces $(2 \mathrm{~cm})(\mathrm{PDJ})$, while the other portion was sliced $(2 \mathrm{~cm})$ with the peel (UPDJ). Each portion was liquefied with a high-speed Kenwood kitchen blender, filtered through a clean muslin cloth and evaluated for proximate, mineral, vitamin, phytochemical and anti-nutrient contents. A 9-point hedonic scale was used to evaluate the sensory properties of the juices. The data were analyzed using a Statistical Package for Social Science, version 21 and significance was set at $p \leq 0.05$.

Results. The UPDJ had significantly $(p<0.05)$ higher carbohydrate $(15.75 \%)$, protein $(4.72 \%)$, fat $(2.65 \%)$ and ash $(0.47 \%)$ contents than PDJ. No significant difference existed in both vitamin and mineral contents of the two samples except for zinc, which was significantly $(p<0.05)$ higher in the PDJ. Phytochemicals and anti-nutrients were significantly $(p<0.05)$ more numerous in the UPDJ than PDJ. The PDJ was rated higher than the UPDJ in all sensory attributes.

Conclusion. The juice samples contain appreciable amounts of carbohydrate, vitamin C, flavonoids, alkaloids, and glycosides. The anti-nutrients were within acceptable levels. Dika fruit is locally available and could be incorporated into meals to promote good health.
\end{abstract}

Keywords: African bush mango, micro-nutrient, phytochemical, proximate composition, organoleptic properties

\section{INTRODUCTION}

Nutrition experts promote increased consumption of fruits and vegetables to eradicate micronutrient deficiency diseases and improve overall health. Micronutrient deficiency diseases are known to be prevalent in populations that subsist largely on refined cereal grains and/or starchy roots and tubers, with low consumption of micronutrient-rich foods. The FAO (2013) estimated that more than 2 billion people globally are deficient in vitamins and minerals, particularly vitamin A, iodine, iron and zinc. Deficiency of micronutrients is the main contributor to the global disease burden. According to the WHO (2011), dietary diversification is 
among the current recommended intervention strategies for the prevention and treatment of micronutrient deficiencies. Many underutilized wild fruits offer potentially novel sources of macro- and micro-nutrients as well as health-promoting antioxidants and phytochemicals for rural populations (Adepoju, 2009; Codjia et al., 2003; Kubola et al., 2011). Processing fruits into various products such as juice will help to prevent post-harvest wastage, make them available all year round, improve economic power and reduce micronutrient deficiencies. Hollis et al. (2009) defined fruit juice as the liquid obtained from fruit or vegetable tissue by mechanically squeezing or macerating their flesh without the application of heat or solvents.

Irvingia gabonensis, also known as dika fruit, African bush mango, wild mango and sweet bush mango, belongs to the Irvingiaceae family. Dika fruits are usually collected from the wild trees in the forest of southeastern Nigeria, Cameroon, Gabon, Congo and some other West African countries (Nwachukwu, 2017). The two common varieties in Nigeria are Irvingia gabonensis and Irvingia wombulu. The Irvingia gabonensis variety has edible fleshy fruits, while the Irvingia wombulu is bitter and not eaten. The dried seeds of the two varieties are used in the preparation of an indigenous soup commonly known as ogbono soup among the Igbo ethnic group in Nigeria. To extract the seed, the pulp is allowed to decay and discarded. This leads to wastage, as the pulp produced could not be eaten. It becomes imperative to process the pulp into fruit juice in order to minimize wastage. There is dearth of information on the nutritional, phytochemical composition and consumer acceptability of fruit juice made from the dika fruit. Filling this knowledge gap will increase its utilization and reduce post-harvest wastage. Dika fruit juice could also be canned to increase its shelf-life and ensure availability. This study evaluated the nutrient, non-nutrient composition and sensory attributes of juices processed from peeled and unpeeled dika fruit.

\section{MATERIALS AND METHODS}

\section{Collection and identification of the sample}

Thirty-five kilograms (35 kg) of ripe and ready-toeat Irvingia gabonensis variety of dika fruits were harvested from nine trees in different locations in

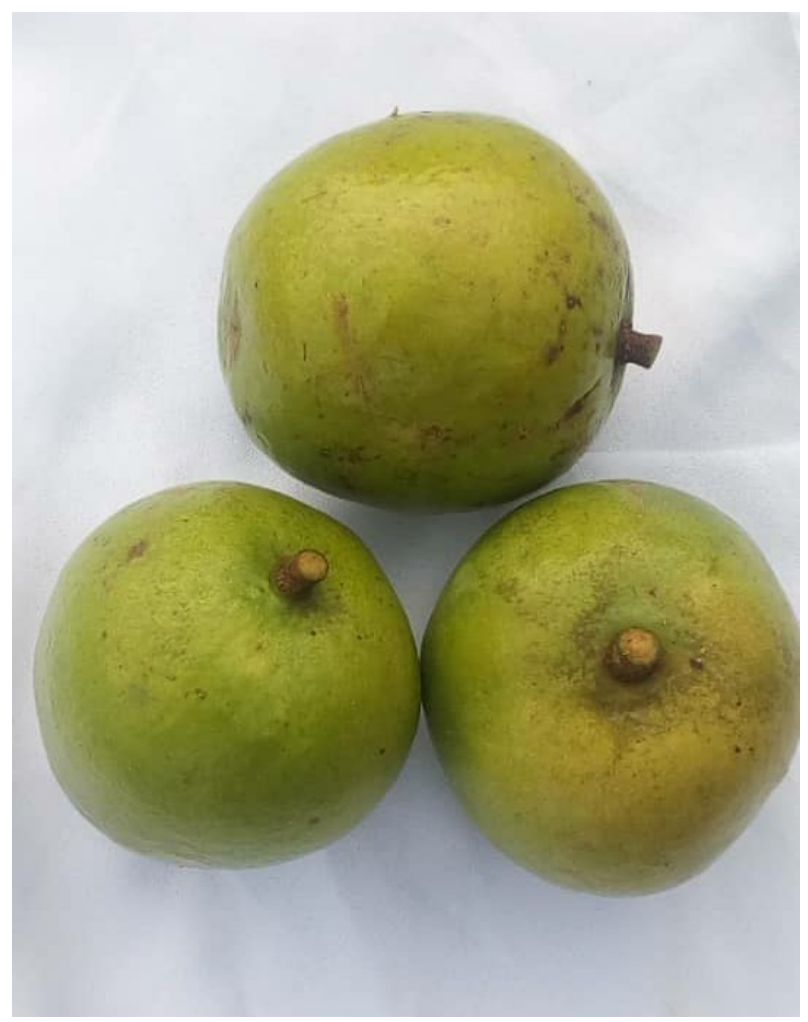

Fig. 1. Picture of dika fruits

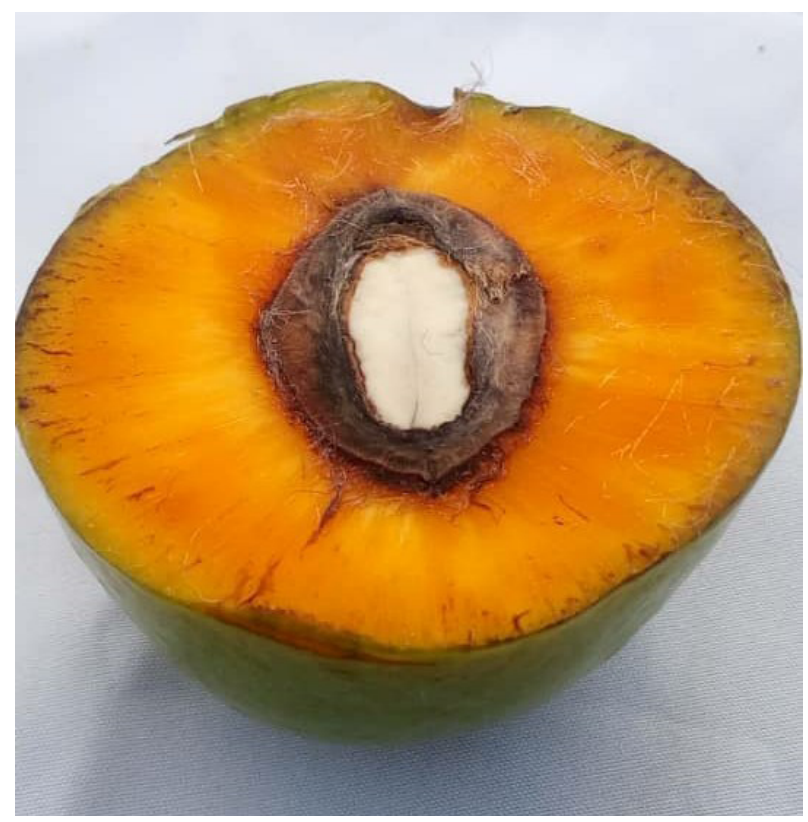

Fig. 2. Longitudinal section of dika fruit 
Nsukka Local Government Area of Enugu State, Nigeria. The sample was identified at the Department of Plant Science and Biotechnology, Faculty of Biological Sciences, University of Nigeria, Nsukka.

\section{Preparation of sample for analysis}

Part of the harvested fruits $(6 \mathrm{~kg})$ was sorted, washed under running water, air-dried and divided into two equal portions of 20 fruits per portion. The skin of one portion was peeled off and the pulp sliced $(2 \mathrm{~cm})$ with a sharp knife and labeled PDJ. The second portion was sliced into the same size with the peel intact and labeled UPDJ. Each portion was blended in two batches to a liquid consistency using a high-speed Kenwood kitchen blender (model, KB-3080) for 5 minutes and filtered through a muslin cloth. The juice produced from each portion was separately poured into sterilized bottles and stored at refrigerating temperature $\left(3^{\circ} \mathrm{C}\right)$ prior to analysis. The remaining dika fruits were processed for sensory evaluation using the same method.

\section{Chemical analysis}

The proximate, vitamin, mineral, anti-nutrient and phytochemical compositions of the samples were determined in triplicate.

\section{Proximate analysis}

Moisture, ash, protein, fat and crude fibre were determined according to the Association of Official Analytical Chemist (AOAC, 2010) methods. Moisture content was determined using the hot air method. Ten (10) $\mathrm{ml}$ of the sample was measured into a crucible and allowed to dry overnight in an oven maintained at $105^{\circ} \mathrm{C}$. The crucible was transferred to the oven again and weighed after 2 hours until constant weight was obtained. Protein was determined using the Kjeldahl method using 6.25 as the conversion factor for converting nitrogen to protein. Ash content was determined by incineration in a muffle furnace. The dry extraction method was used for fat analysis. Crude fat was determined by extraction with petroleum ether using Soxhlet apparatus. Crude fibre determination was done by exhaustive extraction of soluble substances in a sample using a $\mathrm{H}_{2} \mathrm{SO}_{4}$ and $\mathrm{NaOH}$ solution, after which the residue was ashed and the loss in weight recorded as crude fibre. Carbohydrate content was determined by the difference method and dietary fibre by the AOAC (2010) enzymatic-gravimetric method.

\section{Vitamin and mineral analysis}

Thiamin, vitamin $\mathrm{C}$ and folate were determined using the standard fluorimetric methods of AOAC (2010). Pro-vitamin A content was determined by the method adopted from IVACG (1992). Mineral composition was determined by the procedure of AOAC (2010). The ash of the samples was digested and the mineral elements (calcium, zinc and iron) were determined by an atomic absorption spectrophotometer (PYE Unicam SP 2900, UK). Iodine content was determined as described by Fisher et al. (1986).

\section{Phytochemical and anti-nutrient analysis}

Saponin and oxalate were determined by the AOAC (2010) methods. Flavonoid was determined by the double solvent extraction gravimetric procedure described by Harborne (1973). The alkaline precipitation gravimetric method (Harborne, 1973) was used to determine alkaloids. Tannin determination was performed using the Follin-Dennis spectophotometric method described by Pearson (1976). Phytic acid content was determined by the method described by Griffiths and Thomas (1981). Glycoside determination was carried out using the alkaline titrimetric method (AOAC, 2010), while haemagglutinin was determined by the spectrometric method (Onwuka, 2005).

Ethical approval and informed consent. Ethical approval for this study was obtained from the Health Research Ethical committee of Enugu State Ministry of Heath, Nigeria. Written informed consent was obtained from the participants (consumers) before commencing the sensory evaluation.

\section{Sensory evaluation}

The thirty consumers who participated in the sensory evaluation were randomly selected by balloting from staff and final year-students of the Department of Nutrition and Dietetics, University of Nigeria, Nsukka. The texture, colour, taste, flavor and general acceptability of the samples were evaluated on a 9-point hedonic scale ranging from 1 (disliked extremely) to 9 (liked extremely). The sensory assessment was carried out in the Diet Therapy Laboratory. The consumers 
were arranged in such a way as to be unable to see each other's grading sheets. The samples were coded and presented in transparent cups. They were provided with glasses of water to rinse their mouth after testing each sample to avoid carry-over taste.

\section{Statistical analysis}

The data collected were statistically analysed using the Statistical Package for Social Sciences (SPSS), version 21, and expressed as means and standard deviations. The T-test was used to compare the means and significance was accepted at $p \leq 0.05$.

\section{RESULTS AND DISCUSSION}

The proximate composition of juices processed from peeled and unpeeled dika fruit was analysed in this study (Table 1). No significant variation was recorded in the crude fibre content of peeled and unpeeled juice. This is an indication that the peeled juice contained an insignificant amount of fibre. The crude fibre content of the samples was high and approximately twice the values reported for some Nigerian fruits (Ekpete et al., 2013). The experimental juices contained high amounts of dietary fibre, which is considered high for fruit juices. Consumption of dietary fibre has been reported to have an inverse relationship with risk of some chronic diseases (Anderson et al., 2009). A greater amount of

Table 1. Proximate composition of the dika fruit juices, $\%$

\begin{tabular}{lcc}
\hline \multicolumn{1}{c}{ Variable } & $\begin{array}{c}\text { Peeled dika fruit juice } \\
(\text { PDJ) }\end{array}$ & $\begin{array}{c}\text { Unpeeled dika fruit } \\
\text { juice (UPDJ) }\end{array}$ \\
\hline Moisture & $73.68 \pm 0.05^{\mathrm{b}}$ & $70.11 \pm 0.01^{\mathrm{a}}$ \\
Ash & $0.41 \pm 0.01^{\mathrm{a}}$ & $0.47 \pm 0.02^{\mathrm{b}}$ \\
Fat & $0.39 \pm 0.03^{\mathrm{a}}$ & $2.65 \pm 0.09^{\mathrm{b}}$ \\
Protein & $4.04 \pm 0.02^{\mathrm{a}}$ & $4.72 \pm 0.02^{\mathrm{b}}$ \\
Carbohydrate & $15.32 \pm 0.03^{\mathrm{a}}$ & $15.75 \pm 0.05^{\mathrm{b}}$ \\
Crude fibre & $6.16 \pm 0.24^{\mathrm{a}}$ & $6.30 \pm 0.22^{\mathrm{a}}$ \\
Dietary fibre & $4.41 \pm 0.15^{\mathrm{a}}$ & $4.40 \pm 0.31^{\mathrm{a}}$ \\
\hline
\end{tabular}

Values are mean $\pm \mathrm{SD}$ of triplicate determinations. Values with different superscripts in the same row are significantly different at $p \leq 0.05$. moisture was observed per $100 \mathrm{~g}$ of the peeled dika fruit juice compared to the unpeeled. This affirms the report by Morais et al. (2017) that the pulps of different tropical fruits have been shown to have high moisture content, which varied from 73.6 to $93.3 \mathrm{~g}$ per $100 \mathrm{~g}$ in a wet basis. The moisture content of the dika fruit juices compared favourably with the high value reported by Ekpete et al. (2013). The high moisture content observed in the juices suggests that they are prone to increased microbial activity. However, bottling or canning dika fruit juice at a commercial level will increase shelf life, reduce fruit pulp wastage and ensure availability all year round.

The juice processed with the peel intact had more ash content than the peeled fruit juice; fruit peel has been reported to contain significantly higher ash content compared to fruit pulp (Ani and Abel, 2018). The ash content recorded in this study agrees with that reported for African bush mango harvested from Okenya, Idah in Kogi State, Nigeria (Onimawo et al., 2003). Moreover, fat was significantly higher in the unpeeled dika fruit juice than its peeled counterpart, suggesting that dika fruit peel had a higher amount of fat. Fruit peels have been reported to contain fatty acids such as oleic acid, which has a beneficial effect on cardiovascular health (Morais et al., 2017). The fat content of juice from the peeled dika fruit was comparable to the value found in African bush mango juice (Ekpete et al., 2013) but higher than that of sweet orange juice (Chuku and Akani, 2015). The carbohydrate content of the experimental samples also compared favourably with $15.97 \%$ in African bush mango and $16.05 \%$ in Annona muricata (Ekpete et al., 2013) but lower $(14.56 \%)$ than that in sweet orange juice (Chuku and Akani, 2015). Comparatively, the unpeeled dika fruit juice had a higher protein content than the peeled. Though fruits are not considered as protein sources, the dika fruit juices contained appreciable amount of protein. Amino acid analysis of six fruit juice samples by Zeng et al. (2015) showed that aspartic acid, glutamic acid, asparagine, serine and glutamine were present in most of the samples. The protein contents of the experimental samples were higher than that of African bush mango juice (Ekpete et al., 2013) but lower than that reported by Onimawo et al. (2003). Nutrient contents of fruits could be influenced by climatic conditions, soil type and the stage of maturity. These are 
Ibeanu, V. N., Ani, P. N., Eze, P. N. (2020). Nutrient, non-nutrient and sensory profile of peeled and unpeeled dika (Irvingia gabonensis) fruit juice. Acta Sci. Pol. Technol. Aliment., 19(2), 231-237. http://dx.doi.org/10.17306/J.AFS.2020.0812

possible reasons for the varied proximate composition reported by various authors.

The UPDJ had a higher vitamin $\mathrm{C}$, thiamin, betacarotene and folate content than PDJ (Table 2). Fruits are generally known for their high concentration of vitamins (especially vitamins $\mathrm{C}$ and beta-carotene) and minerals (especially electrolytes). The juice samples contained a high amount of vitamin $\mathrm{C}$, hence $100 \mathrm{~g}$ of the dika fruit juice could provide the FAO/WHO (1985) recommended daily dietary intake of vitamin C for an adult male or female. Vitamin $\mathrm{C}$ has some therapeutic benefits, such as skin maintenance and protection, prevention of scurvy and antioxidant activities. The vitamin $\mathrm{C}$ content recorded in these study samples was higher than the 33.03-36.13 mg reported by Okiei et al. (2009). Low calcium, zinc and iron contents were recorded in this study (Table 2). Higher calcium, zinc and iron contents were reported in juice processed from Irvingia gabonensis sourced from Port Harcourt, Nigeria (Ekpete et al., 2013). The differences in values could be attributed to the stage of maturity and varietal differences, which Appiah et al. (2011) observed in mineral analysis of Keitt mango. Iodine was not detected in the juice samples, indicating depleted iodine content in the soil. The concentration of iodine in plants reflects the iodine content of the soil in which it is grown (Fuge, 2005).

Table 2. Vitamin and mineral composition (mean $\pm \mathrm{SD}$ ) of dika fruit juices per $100 \mathrm{~g}$

\begin{tabular}{lcc}
\hline \multicolumn{1}{c}{ Variable } & $\begin{array}{c}\text { Peeled dika fruit } \\
\text { juice (PDJ) }\end{array}$ & $\begin{array}{c}\text { Unpeeled dika } \\
\text { fruit juice (UPDJ) }\end{array}$ \\
\hline Vitamin C, mg & $70.49 \pm 44.03^{\mathrm{a}}$ & $81.48 \pm 45.94^{\mathrm{b}}$ \\
Thiamin, mg & $0.36 \pm 0.07^{\mathrm{a}}$ & $0.41 \pm 0.07^{\mathrm{a}}$ \\
Beta-carotene, $\mu \mathrm{g} \mathrm{RE}$ & $5.43 \pm 0.76^{\mathrm{a}}$ & $7.27 \pm 0.57^{\mathrm{a}}$ \\
Folate, $\mu \mathrm{g}$ & $0.62 \pm 0.03^{\mathrm{a}}$ & $0.70 \pm 0.03^{\mathrm{a}}$ \\
Calcium, mg & $0.39 \pm 0.01^{\mathrm{b}}$ & $0.14 \pm 0.02^{\mathrm{a}}$ \\
Zinc, mg & $0.71 \pm 0.04^{\mathrm{b}}$ & $0.42 \pm 0.02^{\mathrm{a}}$ \\
Iron, mg & $0.08 \pm 0.01^{\mathrm{a}}$ & $0.13 \pm 0.02^{\mathrm{a}}$ \\
Iodine & not detected & not detected \\
\hline
\end{tabular}

Values with different superscripts in the same row are significantly different at $p \leq 0.05$.
Table 3. Phytochemical composition (mean $\pm \mathrm{SD}$ ) of dika fruit juices

\begin{tabular}{lcc}
\hline $\begin{array}{c}\text { Variable } \\
\mathrm{mg} / 100 \mathrm{~g}\end{array}$ & $\begin{array}{c}\text { Peeled dika fruit juice } \\
\text { (PDJ) }\end{array}$ & $\begin{array}{c}\text { Unpeeled dika fruit } \\
\text { juice (UPDJ) }\end{array}$ \\
\hline Flavonoids & $380.83 \pm 9.02^{\mathrm{a}}$ & $399.29 \pm 11.96^{\mathrm{b}}$ \\
Saponins & $0.26 \pm 0.13^{\mathrm{a}}$ & $0.50 \pm 0.02^{\mathrm{b}}$ \\
Alkaloids & $32.21 \pm 4.20^{\mathrm{a}}$ & $39.99 \pm 1.67^{\mathrm{b}}$ \\
Glycosides & $11.24 \pm 0.16^{\mathrm{a}}$ & $12.50 \pm 0.56^{\mathrm{b}}$ \\
\hline
\end{tabular}

Values with different superscripts in the same row are significantly different at $p \leq 0.05$.

Studies (Ani and Abel, 2018; Ibeanu et al., 2014) have shown that fruit peel and seeds contain bioactive compounds which provide desirable health benefits. Dika fruit juices are good sources of flavonoids and alkaloids. These phytochemicals were significantly higher in the unpeeled dika fruit juice (Table 3). Flavonoids have anti-microbial, anti-oxidant, anti-inflammatory and anti-allergic effects, while alkaloids play an important role in the defense system and possess anti-microbial, anti-HIV and anti-parasitic properties (Bouayad et al., 2012). Oxalate, phytate, tannins and haemagglutinin (anti-nutrients) were significantly $(p<0.05)$ higher in UPDJ than PDJ (Table 4). It is likely that these natural compounds which interfere with absorption of nutrients were more concentrated on the fruit peel. The function of anti-nutrients in the body depends on the quantity. Tannins are known to act as phytochemicals at low levels with anticarcinogenic

Table 4. Anti-nutrients composition (mean $\pm \mathrm{SD}$ ) of dika fruit juices per $100 \mathrm{~g}$

\begin{tabular}{lcc}
\hline \multicolumn{1}{c}{ Variable } & $\begin{array}{c}\text { Peeled dika } \\
\text { fruit juice } \\
\text { (PDJ) }\end{array}$ & $\begin{array}{c}\text { Unpeeled dika } \\
\text { fruit juice } \\
\text { (UPDJ) }\end{array}$ \\
\hline Oxalate, $\mathrm{mg} / 100 \mathrm{~g}$ & $30.60 \pm 3.12^{\mathrm{a}}$ & $39.60 \pm 3.12^{\mathrm{b}}$ \\
Phytate, $\mu \mathrm{g} / 100 \mathrm{~g}$ & $3.38 \pm 0.31^{\mathrm{a}}$ & $4.35 \pm 0.10^{\mathrm{b}}$ \\
Tannin, $\mathrm{mg} / 100 \mathrm{~g}$ & $40.58 \pm 1.33^{\mathrm{a}}$ & $50.16 \pm 0.55^{\mathrm{b}}$ \\
Haemagglutinin, $\mathrm{mg} / 100 \mathrm{~g}$ & $14.19 \pm 0.01^{\mathrm{a}}$ & $14.30 \pm 0.01^{\mathrm{b}}$ \\
\hline
\end{tabular}

Values with different superscripts in the same row are significantly different at $p \leq 0.05$. 
and antimutagenic potential (Chung et al., 1998). The tannin and phytate contents of the samples were below the safe level reported by Schiavone et al. (2008). Phytate are known to bind iron, zinc and vitamin D making them unavailable for absorption. The tolerable limit of oxalate $(105 \mathrm{mg} / 100 \mathrm{~g})$ reported by WHO (2003) was higher than the value in the study samples. Haemagglutinins are sugar-binding proteins which are known to bind and agglutinate red blood cells. However, the toxic level of haemagglutinin $(25 \mathrm{mg} / 100 \mathrm{~g})$ as reported by Munro and Basir (1973) was higher than the value found in the study samples.

Table 5. Mean scores assigned to dika fruit juice in the 9-point hedonic scale

\begin{tabular}{lcc}
\hline \multicolumn{1}{c}{ Variable } & $\begin{array}{c}\text { Peeled dika fruit } \\
\text { juice (PDJ) }\end{array}$ & $\begin{array}{c}\text { Unpeeled dika } \\
\text { fruit juice (UPDJ) }\end{array}$ \\
\hline Texture & $7.4 \pm 1.8^{\mathrm{a}}$ & $7.1 \pm 1.8^{\mathrm{a}}$ \\
Colour & $8.0 \pm 1.1^{\mathrm{b}}$ & $7.5 \pm 1.5^{\mathrm{a}}$ \\
Taste & $5.7 \pm 2.1^{\mathrm{b}}$ & $5.1 \pm 1.9^{\mathrm{a}}$ \\
Flavour & $6.1 \pm 2.0^{\mathrm{b}}$ & $5.2 \pm 2.1^{\mathrm{a}}$ \\
General acceptability & $5.9 \pm 2.2^{\mathrm{b}}$ & $4.4 \pm 2.1^{\mathrm{a}}$ \\
\hline
\end{tabular}

Values with different superscripts in the same row are significantly different at $p \leq 0.05$.

Hedonic scale: 1 - disliked extremely, 2 - disliked very much, 3 - disliked, 4 - disliked mildly, 5 - neither liked nor disliked, 6 - liked mildly, 7 - liked, 8 - liked very much, 9 - liked extremely.

The sensory attributes (colour, texture, flavour, and taste) of the PDJ and the UPDJ were rated above average (Table 5). The PDJ was rated significantly $(p<0.05)$ higher than the UPDJ in sensory attributes, except for texture, which showed no significant difference. This was expected, as the two samples had similar particle size. The significant lower colour rating of the UPDJ compared with the PDJ could be associated with the undesirable colour introduced by the peel. Employing a more refined processing method could give rise to a clearer high-quality juice. Taste had the lowest rating among the attributes, although this could be improved by adding a sweetener.

\section{CONCLUSION}

This study showed that dika fruit juice has appreciable amounts of carbohydrate, protein, fibre, vitamin $\mathrm{C}$, flavonoid, alkaloid, and glycoside. The unpeeled dika fruit juice was significantly higher in ash, fat, protein, carbohydrate, vitamin $\mathrm{C}$, phytochemical and antinutrient contents, However, the peeled dika fruit juice was rated higher in sensory attributes. The amount of anti-nutrients in the juice samples were below the toxic levels. Considering the acceptance rating and the beneficial nutritive constituents, utilization of dika fruit should be promoted.

\section{REFERENCES}

Adepoju, O. T. (2009). Proximate composition and micronutrient potentials of three locally available wild fruits in Nigeria. Afr. J. Agric. Res., 4(9), 887-892.

Anderson, J. W., Baird, P., Davis, Jr, R. H., Ferreri, S., Knudtson, M., Koraym, A., ..., Williams, C. L. (2009). Health benefits of dietary fibre. Nutr. Rev., 67(4), 188-205.

Ani, P. N., Abel, H. C. (2018). Nutrient, phytochemical, and antinutrient composition of Citrus maxima fruit juice and peel extract. Food Sci. Nutr., 6, 653-658. https:// doi.org/10.1002/fsn3.604

AOAC (2010). Official method of analysis (20 $0^{\text {th }} \mathrm{ed}$.). Washington, DC: Association of Official Analytical Chemists.

Appiah, F., Kumah, P., Idun, I. (2011). Effect of ripening stage on composition, sensory qualities and acceptability of Keitt mango (Mangifera indica L.) chips. Afr. J. Food Agric. Nutr. Dev., 11(5), 5096-5109.

Bouayad, N., Rharrabe, K., Lamhamdi, M., Nourouti, N. G., Sayah, F. (2012). Dietary effects of harmine, a $\beta$-carboline alkaloid, on development, energy reserves and $\alpha$-amylase activity of Plodia interpunctella Hübner (Lepidoptera: Pyralidae). Saudi J. Biol. Sci., 19(1), 73-80.

Chuku, E. C., Akani, N. P. (2015). Determination of proximate composition and microbial contamination of fresh juice from three citrus species. Int. J. Biol. Med. Res., 1(1). Retrieved from www.iiardonline.org

Chung, K. T., Wong, T. Y., Wei, C. I., Huang, Y. W., Lin, Y. (1998). Tannins and human health: a review. Crit. Rev. Food Sci. Nutr., 38(6), 421-464.

Codjia, J. C., Assogbadjo, E., Ekue, M. (2003). Diversity and local valorisation of vegetal edible products in Benin. Cah. Agric., 12(5), 321-331. 
Ekpete, O. A., Edori, O. S., Fubara, E. P. (2013). Proximate and mineral composition of some Nigerian fruits. Br. J. Appl. Sci. Technol., 3(4), 1447-1454.

FAO (2013). Food balance sheets/bulk downloads. Retrieved 15 March, 2020 from: http://faostat3.fao.org/ download/FB/FBS/E

FAO/WHO (1985). Food and Agricultural Organization / World Health Organization Recommended Intakes. Ascorbic acid requirements: WHO Report No. 452.

Fisher, P. W., L'Abbe, M. R., Giroux, A. (1986). Colorimetric determination of total iodine in foods by iodide-catalyzed reduction of $\mathrm{Ce}+4$. J. Assoc. Off. Anal. Chem., 69, 687-689.

Fuge, R. (2005). Soils and iodine deficiency. In O. Selinus, B. Alloway, J. A. Centeno, R. B. Finkelman, R. Fuge, U. Lindh, P. Smedley (Eds.), Essentials of Medical Geology: Impacts of the Natural Environment on Public Health. Singapore: Elsevier Acad. Press.

Griffiths, D. W., Thomas, T. A. (1981). Phytate and total phosphorus content of field beans (Viciafaba). J. Sci. Food Agric., 32, 187-192.

Harborne, J. B. (1973). Phytochemical methods: A guide to modern techniques of plant analyses (pp. 18-215). New York: Chapman and Hall.

Hollis, J. H., Houchins, J. A., Blumberg, J. B., Mattes, R. D. (2009). Effects of Concord grape juice on appetite, diet, body weight, lipid profile, and antioxidant status of adults. J. Am. Coll. Nutr., 28(5), 574-582.

Ibeanu, V. N., Onyechi, A. U., Ani, P. N., Aneke, C. V. (2014). Anti-nutrient, phytochemical and free fatty acid composition of dehulled and undehulled sweet princess watermelon (Citrullus lanatus) seed flour. Pakistan J. Nut., 13(10), 589-592.

IVACG (International Vitamin A Consultative Group) (1992). Reprint of selected methods for the analysis of Vitamin A and carotenoids in nutrition surveys (pp. 1618). Washington D.C.: The Nutrition Foundation.

Kubola, J., Siriamornpun, S., Meeso, N. (2011). Phytochemicals, vitamin $\mathrm{C}$ and sugar content of Thai wild fruits. Food Chem., 126, 972-981.
Morais, D. R., Eliza, M., Rotta, E., Sheisa, C. S., Elton, G. B., Rúbia, M. S., ..., Jesuí, V. V. (2017). Proximate composition, mineral contents and fatty acid composition of the different parts and dried peels of tropical fruits cultivated in Brazil. J. Braz. Chem. Soc., 28, 308-318.

Munro, A., Basir, O. (1973). Oxalate in Nigeria vegetables. West Afr. J. Biol. Appl. Chem., 12, 14-18.

Nwachukwu, C. (2017). Ogbono (Dika) Irvingia gabonensis. Afro Food Feeds. Retrieved 15 March 2020 from: http://afrofoodfeeds.org/ogbono-dika-irvingia-gabonensis

Okiei, W. M., Ogunlesi, A. L., Obakachi, V., Osunsanmi, M., Nkenchor, G. (2009). The voltammetric and titrimetric determination of ascorbic acid levels in tropical fruit samples. Int. J. Electrochem., 4, 276-287.

Onimawo, I. A., Oteno, F., Orokpo, G., Akubor, P. I. (2003). Physiochemical and nutrient evaluation of African bush mango (Irvingia gabonensis) seed and pulp. Plant Foods Hum. Nutr., 58(3), 1-6.

Onwuka, G. I. (2005). Food analysis and instrumentation theory and practice, Napthali fruits. Lagos, 160.

Pearson, D. (1976). Chemical analysis of foods (pp. 7-14). Edinburgh, UK: Churchill Livingstone.

Schiavone, A., Guo, K., Tassone, S., Gasco, L., Hernandez, E., Denti, R. (2008). Effects of a natural extracts of chestnut wood on digestibility, performance traits and nitrogen balance of broiler chicks. Poult. Sci., 87, 521-527.

WHO (2003). Post-harvest and pressing technology of staple food. Tech, Compendium, WHO, Agric. Sci. Bull., $88,171-179$.

WHO (2011). World Health Organization. Guideline: Use of multiple micronutrient powders for home fortification of foods consumed by infants and children 6-23 months of age. Geneva: World Health Organization.

Zeng, F., Ou, J., Huang, Y., Li, Q., Xu, G., Liu, Z., Yang, S. (2015). Determination of 21 free amino acids in fruit juices by HPLC using a modification of the 6-aminoquinolyl-N-hydroxysuccinimidyl carbamate (AQC) method. Food Anal. Meth., 8, 428-437. 